\title{
LITTLE ICE AGE (NEOGLACIAL) PALEOENVIRONMENTAL CONDITIONS AT SIPLE STATION, ANTARCTICA
}

\author{
by \\ Ellen Mosley-Thompson, Lonnie G. Thompson \\ (Byrd Polar Research Center, The Ohio State University, Columbus, OH 43210, U.S.A.) \\ Pieter M. Grootes \\ (Quaternary Isotope Laboratory, University of Washington, Seattle, WA 98105, U.S.A.) \\ and \\ N. Gundestrup \\ (University of Copenhagen, Geophysical Institute, Copenhagen, Denmark)
}

\section{ABSTRACT}

The 550 -year records of $\delta^{18} \mathrm{O}$ and dust concentrations from Siple Station, Antarctica suggest warmer and less dusty atmospheric conditions from 1600 to 1830 A.D. which encompasses much of the northern hemisphere Little Ice Age (LIA). Dust and $\delta^{18} \mathrm{O}$ data from South Pole Station indicate that the opposite conditions (e.g. cooler and more dusty) were prevalent there during the LIA. Meteorological data from 1945-85 show that the LIA temperature opposition between Amundsen-Scott and Siple, inferred from $\delta^{18} \mathrm{O}$, is consistent with the present spatial distribution of surface temperature. There is some observational evidence suggesting that under present conditions stronger zonal westerlies produce a temperature pattern similar to that of the LIA. These regional differences demonstrate that a suite of spatially distributed, high resolution ice-core records will be necessary to characterize the LIA in Antarctica

\section{INTRODUCTION}

A 550-year record of dust concentrations and oxygen isotopic ratios has been obtained from a $302 \mathrm{~m}$ core drilled in $1985-86$ at Siple Station $\left(75^{\circ} 55^{\prime} \mathrm{S}\right.$; $84^{\circ} 15^{\prime} \mathrm{W}$; $1054 \mathrm{~m}$ a.s.1.), Antarctica (Fig. 1). Siple lies between the Antarctic Peninsula region which is characterized by a complex near-surface wind regime (Schwerdtfeger and Amaturo, 1979) and the high inland polar plateau. To the east of the Peninsula the continental character of the meteorological regime leads to a very cold Antarctic coastal belt while maritime conditions dominate to the west. It is likely that the Siple region is not dominated consistently by a single meteorological regime, but is a sensitive region of transition. This paper assesses the spatial and temporal scales for which the 550-year ice-core record may serve as a useful environmental proxy record. Finally, the dust concentrations and oxygen isotopic ratios $\left(\delta^{18} \mathrm{O}\right)$ are presented and discussed in light of two other ice-core records encompassing the (LIA) period.

\section{TIME SCALE CONSTRUCTION}

The $302 \mathrm{~m}$ Siple core was cut into three sets of 5757 samples each for microparticle concentration (MPC), electrical conductivity (EC) and $\delta^{18} \mathrm{O}$ analyses to isolate any potential seasonal signal, and thus produce the best possible time scale. The particulate concentrations are the lowest measured in polar samples (Thompson and Mosley-

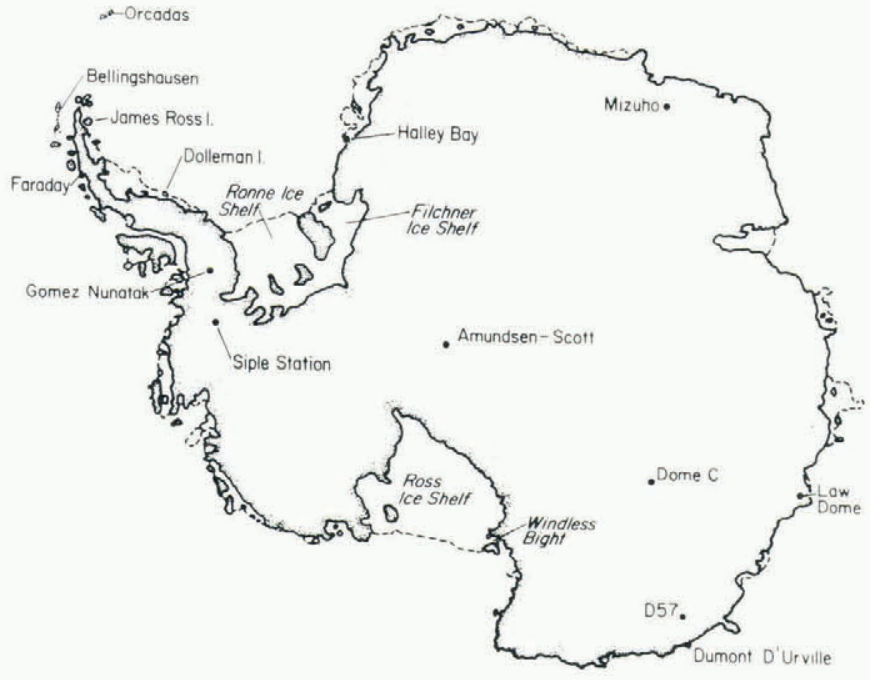

Fig. 1. Core sites and meteorological stations discussed in the text.

Thompson, 1982). Although a weak seasonal deposition pattern exists, concentration variations associated with individual storm events makes identification of annual layers difficult and increases the subjectivity of the interpretation (Mosley-Thompson and others, 1989). The electrical conductivity of liquid samples (EC), which reflects the total ionic concentration, does not show a seasonal signal. This contrasts with the direct current (DC) measurements (Schwander, 1984) which show excellent seasonality for the upper $144 \mathrm{~m}$ of a core drilled in 1983. The lack of seasonal variation in EC results from the combination of a summer peak in $\mathrm{SO}_{4}^{2-}$ concentration and a winter peak in $\mathrm{Cl}^{-}$(Dai and others, 1989). On the other hand, the DC conductivity which reflects the total $\mathrm{H}^{+}$concentration is more closely associated with $\mathrm{SO}_{4}^{2-}$ concentrations which have a very strong seasonal variation.

The $\delta^{18} \mathrm{O}$ exhibits excellent seasonality throughout the entire $302 \mathrm{~m}$ and has been shown to be reproducible among multiple shallow cores bracketing the drill site (MosleyThompson and others, 1989). The current time scale for the $302 \mathrm{~m}$ Siple core is based only on a seasonality of $\delta^{18} \mathrm{O}$, but will be refined (if necessary) after cross checking with the continuous $\mathrm{SO}_{4}^{2-}$ analyses now underway. $\mathrm{SO}_{4}^{2-}$ is deposited seasonally and the annual signal is well preserved 
(Dai and others, 1989). Additionally, the $\delta^{18} \mathrm{O}$-based time scale (1985 core) and Schwander's DC conductivity-based time scale (1983 core) agree well (1757 A.D. versus 1753 A.D., respectively) at $144 \mathrm{~m}$.

\section{COMPARISON WITH METEOROLOGICAL RECORDS}

The importance of the 550-year record as an environmental proxy depends upon whether it is representative of an area larger than the vicinity of the drill site. The small spatial scale $(\mathrm{km})$ reproducibility of the preserved records has been demonstrated (Mosley-Thompson and others, 1989; Dai and others, 1989). The utility of the Siple record as an indicator of larger scale or regional climatic trends is addressed here.

For this assessment the only surface meteorological data from Antarctica are temperature, pressure and precipitation (Department of Energy, 1987). Of these, temperature is most directly associated with a measured ice-core property. For comparison with the surface temperature records the $\delta^{18} \mathrm{O}$ values for individual samples have been averaged over each annual unit. The implicit assumption that accumulation occurs evenly throughout the year may introduce a bias. Precipitation does fall throughout the year at Siple in association with persistent cyclonic activity, but the annual distribution of precipitation is unknown. Other limitations of $\delta^{18} \mathrm{O}$ as a condensation temperature proxy are recognized.
Factors such as distance from the source (e.g. sea-ice extent (Bromwich and Weaver, 1983), storm track trajectory) and isotopic composition of the source also contribute to $\delta^{18} \mathrm{O}$ at the deposition site (see Peel and others, 1988 for a discussion). The relationships among these controlling factors are complex and their relative importance will vary. with geographic location. Field studies necessary to quantify the $\delta^{18} \mathrm{O}$-air temperature relationship (e.g. Jouzel and others, 1983 for Amundsen-Scott) have not been conducted at Siple Station. For the purpose of this paper the $\delta^{18} \mathrm{O}$ is assumed to provide a proxy history for the condensation temperature of Siple precipitation. The classical interpretation of $\delta^{18} \mathrm{O}$ for polar ice sheets is adopted, that is more (less) negative ratios imply cooler (warmer) condensation temperatures.

Comparison of the Siple $\delta^{18} \mathrm{O}$ record with observed surface temperatures for Antarctic stations is possible only from 1943 to 1985 A.D. Figure 2 (A-D,I) illustrates the longest and most complete records along with the annual $\delta^{18} \mathrm{O}$ history from Siple (Fig. 2E). The annual average temperatures and $\delta^{18} \mathrm{O}$ are expressed as departures from their respective time series means. On the left are stations from the Antarctic Peninsula region. Islas Orcadas $\left(60^{\circ} 44^{\prime} \mathrm{S} ; 44^{\circ} 44^{\prime} \mathrm{W}\right)$ and Bellingshausen $\left(62^{\circ} 12^{\prime} \mathrm{S} ; 58^{\circ} 56^{\prime} \mathrm{W}\right)$ represent the northern end of the Peninsula while Faraday $\left(65^{\circ} 15^{\prime} \mathrm{S} ; 64^{\circ} 16^{\prime} \mathrm{W}\right)$ is characteristic of the western coastal region. Halley $\left(75^{\circ} 30^{\prime} \mathrm{S} ; 26^{\circ} 39^{\prime} \mathrm{W}\right)$, on the extreme eastern edge of the Weddell Sea, characterizes the colder, more continental regime to the east of the Peninsula. On the
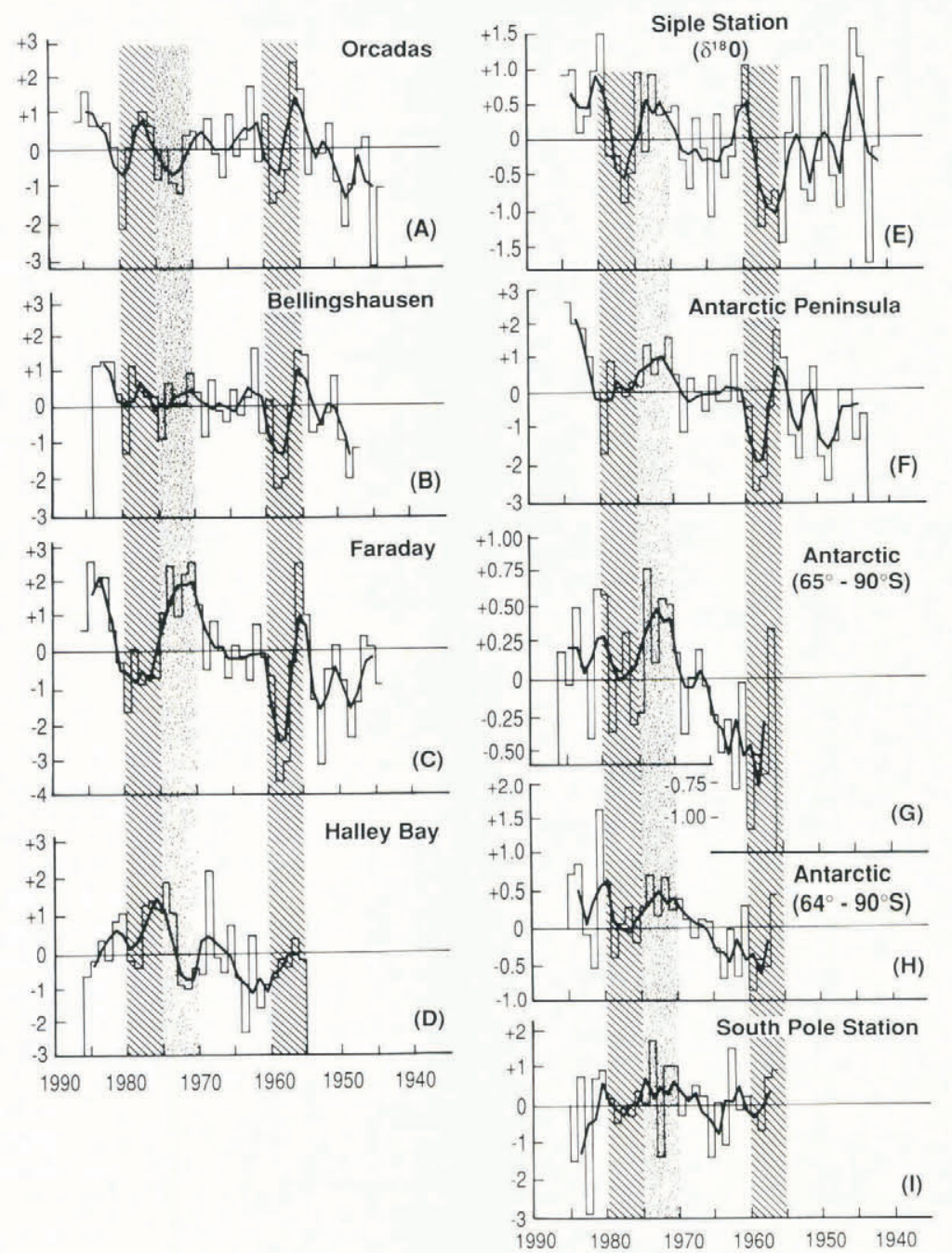

Fig. 2. Annual temperatures (histogram) and three-year unweighted running means (solid line) illustrated for Islas Orcadas (A), Bellingshausen (B), Faraday (C), Halley (D) and South Pole (I); see Fig. 1 for locations. Included are three temperature composites: (F) Antarctic Peninsula (Limbert, 1984; Peel and others, 1988); (G) Antarctic $\left(65-90^{\circ}\right)$ temperature trends (Raper and others, 1984); (H) Antarctic $\left(64-90^{\circ} \mathrm{S}\right)$ temperature trends (Hansen and Lebedeff, 1987). The $\delta^{18} \mathrm{O}(\% \%)$ record (E) from Siple is included for the comparable time period. 
right (Fig. 2) are the Siple $\delta^{18} \mathrm{O}$ record and the Amundsen-Scott (South Pole) temperature record. Also included are the Antarctic Peninsula composite (Fig. 2F) compiled by Limbert (1984) and updated by Peel and others (1988); an Antarctic $\left(65-90^{\circ} \mathrm{S}\right)$ synthesis by areal averaging (Fig. 2G) by Raper and others (1984) and updated to 1986 (DOE, 1987); and a spatially averaged trend analysis (Fig. $2 \mathrm{H}$ ) for $64^{\circ}$ to $90^{\circ} \mathrm{S}$ by Hansen and Lebedeff (1987).

The Halley and Amunden-Scott records bear the least resemblance to the two continental-scale composites and the Peninsula composite (Fig. 2). It is likely that the continental temperature composites are biased toward coastal conditions as only three inland stations (Amundsen-Scott, Vostok and Byrd) have long records. Observations at Byrd ended in 1970. Further, there is some areal bias toward the Peninsula region where the longer and more complete records exist (see fig. 2 in both Raper and others, 1984 and Hansen and Lebedeff, 1987). If South Pole is characteristic of the high polar plateau (above $2500 \mathrm{~m}$ elevation), then much of the areal extent of the continent may not be represented well by these composites.

The temperature and $\delta^{18} \mathrm{O}$ data both contain fairly large interannual variability and thus a three-year unweighted running mean (solid line) is used to highlight multi-year trends. Despite its zonal symmetry, the southern hemisphere atmospheric circulation is characterized by interannual variability larger than that in the northern hemisphere (Trenberth, 1984). The distribution of storm tracks and preferred regions of blocking are tied to the planetary waves, and thus to the position of the mean jet stream. Rogers (1983) found that interannual temperature variability at a site reflects similar variability in the longitudinal positions of the upper level waves and associated surface cyclones. Positions of these features are controlled partially by the distribution of Antarctic sea ice and hence, by sea-surface temperatures (Carleton, 1984; Trenberth, 1984). Thus, the high interannual temperature variability results from large-scale changes from year to year in the position of the jet stream and preferred storm tracks which control the penetration of warm air to the Antarctic interior. Likewise, the annual $\delta^{18} \mathrm{O}$ averages exhibit substantial variability partially in response to atmospheric temperatures, but also in response to the frequency, duration, intensity and seasonality of precipitation from cyclonic storms.

The only long temperature record, Islas Orcadas (1903-85), has been shown (Jones and others, 1986a; Raper and others, 1984) to be unrepresentative of both the Antarctic mean temperature series and the southern hemisphere $\left(0-60^{\circ} \mathrm{S}\right)$ composite for the $1957-83$ period. This is due in part to a "remarkable" and statistically significant change in the temperature field which occurred in 1970. Schwerdtfeger (1976) noticed that from 1957 to 1970 the temperature relationship between Orcadas and Faraday (formerly Argentine Island) was consistent with colder temperatures at Faraday. However, in 1970 this relationship reversed (Fig. 2A,C). An analysis of the sea level pressure field lead Schwerdtfeger to conclude that increased frequency and strength of winds from the north-west increased the advection of warmer maritime air from the south-eastern Pacific to the west coast of the Peninsula. Rogers' (1983) analysis suggested that a shift in the preferred location of surface cyclones and upper-level waves occurred. Figure 2 illustrates that this warm period occurred over a much larger area than the west coast of the Antarctic Peninsula as first suggested by Schwerdtfeger.

Comparison of the records in Figure 2 reveals three periods of persistent (multi-year) and geographically extensive temperature trends: $1975-80,1970-75$ and 1955-60. The spatial patterns of these trends are not constant with time; that is, the temperature relationship between specific station pairs is not temporally consistent. For example, the 1970-75 warm period which was so prominent at Faraday (Fig. 2; stipple) is present at Siple, in the Peninsula and Antarctic composites, and is less prominent at South Pole. Alternately, Halley and Islas Orcadas exhibit cooler temperatures while little change occurred at Bellingshausen near the tip of the Peninsula. It is interesting that the cooling trend in the late 1970s is prominent only in those records with warming earlier in the decade. This consistent spatial pattern may suggest that the consecutive warming and cooling throughout the decade were part of a large-scale circulation pattern which exhibited long-term persistence.

The spatial characteristics of the temperature pattern for the cooler period from 1955-60 (Fig. 2; hatched pattern) are different from those of the 1975-80 cool period. Cooler temperatures were prevalent along the entire north-south axis of the Peninsula, but did not extend across the ice shelf to Halley. The cooling was modest at AmundsenScott. A minor shift in the preferred locations for largescale circulation features may produce such a result (Rogers, 1983). Winter mean surface temperature trends in Antarctica have been linked to slow (multi-year) variations in atmospheric long waves (van Loon and Williams, 1977) suggesting that mid-latitude large-scale circulation plays a significant role in the spatial variability of temperature over the continent. These data illustrate the regional differences that exist over Antarctica and explain why no single meteorological record provides a consistent picture of Antarctic temperature trends.

Rogers (1983) used a factor analysis to study the spatial variability of seasonal mean temperature departures. $\mathrm{He}$ reported an opposition in temperature anomalies between continental stations and those on or near the Antarctic Peninsula in all seasons but spring. For $1958-80$ the strength of the zonal westerlies (estimated from height differences across six pairs of mid-latitude and Antarctic stations) was strongly tied to the Peninsula-continent temperature opposition pattern in winter and summer. He found that in years when zonal westerlies are strongest, temperatures are anomalously cold at South Pole Station and anomalously warm in the Peninsula area.

Swanson and Trenberth (1981) also reported an opposition in the long-term temperature trends (1957-79) between the north-east sector (roughly $0-90^{\circ}$; including AmundsenScott) and the rest of the continent including much of west Antarctica and the Peninsula. A principal components analysis (Raper and others, 1984) of the spatial characteristics of Antarctic annual and winter temperatures (1957-83) support the Swanson and Trenberth results: that is, negative loadings (a cooler trend) in the sector between $40^{\circ} \mathrm{E}$ and $30^{\circ} \mathrm{W}$ and positive loadings (warming trend) for the rest of the continent including the Peninsula. Figure 2 illustrates that the major multi-year trends in both the Peninsula and continental-scale composites are reflected in the Siple Station $\delta^{18} \mathrm{O}$ record $(1940-85)$. Although Siple lies between the Peninsula and the polar plateau, these data suggest that the Siple ice-core record is more reflective of conditions in the Peninsula region.

\section{COMPARISON WITH OTHER ICE-CORE $\delta^{18} \mathrm{O}$ RECORDS}

To assess the isotope/temperature relationship in the Peninsula, Peel and others (1988) compared temperature records from Faraday, Halley and the Antarctic Peninsula composite (Limbert, 1984) with isotopic records from Gomez Nunatak and Dolleman Island. Here a similar approach is taken to assess the significance of the Siple record for reconstruction of environmental conditions in that region.

Figure 3 compares the annual $\delta^{18} \mathrm{O}$ averages for Dolleman, Gomez (Peel and others, 1988), and Siple and the annual $\delta \mathrm{D}$ averages from James Ross Island (Aristarain and others, 1986) for 1937-85, the period of overlap. In each case, identification of the annual unit for averaging is obtained from the published $\delta^{18} \mathrm{O}$ or $\delta \mathrm{D}$ record. Therefore, potential errors among the respective time scales are not addressed in this paper. As with the annual temperature data, the isotopic variability from year to year among the cores is high.

All four records contain similarities in the longer trends. For example, less negative $\delta^{18} \mathrm{O}$ ratios characterize the 1970-75 warm period. Further, with the exception of the James Ross Island record, the average $\delta^{18} \mathrm{O}$ values are more negative from the mid-1940s to the mid-1960s possibly suggesting cooler temperatures. In the years preceding 1945 all four records show less negative $\delta^{18} \mathrm{O}$ values (warmer conditions), but the records are too short to assess trend.

The five-year $\delta^{18} \mathrm{O}$ averages for the four cores are illustrated in Figure 4 and the two longer records (James 


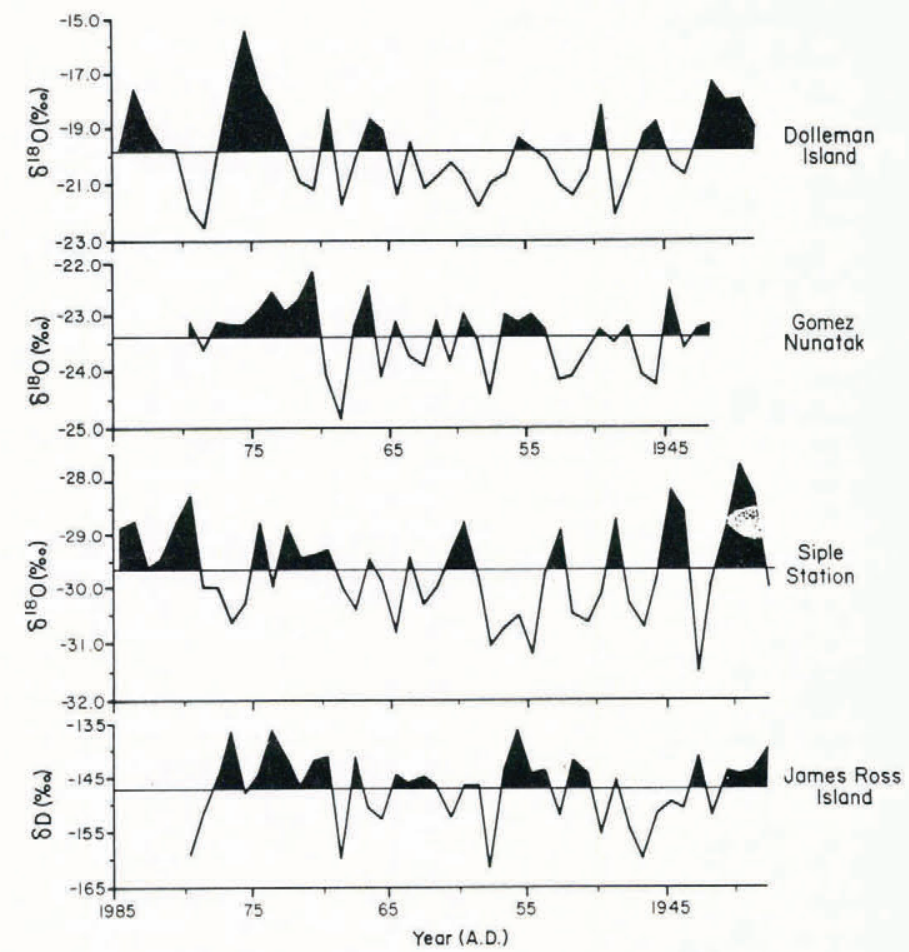

Fig. 3. Annual $\delta^{18} \mathrm{O}$ averages illustrated for Dolleman Island, Gomez Nunatak (Peel and others, 1988), James Ross Island (Aristarain and others, 1986) and Siple.

Ross and Siple) extend to 1850 A.D. Prior to 1945 the records indicate warmer conditions in the 1930s and early 1940s, consistent with global and hemispheric surface temperature trends (Hansen and Lebedeff, 1987; fig. 6) and cooling from the mid-1940s to the mid-1960s. However, when the two longer $\delta^{18} \mathrm{O}$ records are compared with hemispheric $\left(0-60^{\circ} \mathrm{S}\right)$ temperature reconstructions (18501985 A.D.), the prominent warming trend from the late-nineteenth century is absent. At Siple the $\delta^{18} \mathrm{O}$ values from 1865 to 1945 A.D. appear consistently enriched (less negative) possibly reflecting condensation temperatures warmer than today. The James Ross record suggests the warmest temperatures in the mid- to late 1800 s followed by a steady decline until the 1970-75 warm event. The broad trends in these two ice-core records do not support a postLIA warming trend which is a very prominent feature in both hemispheric temperature composites (Jones and others, 1986a, b; Hansen and Lebedeff, 1987).

\section{LIA RECORD $\left(8^{18} \mathrm{O}\right.$ AND DUST)}

The Siple record extending to 1430 A.D. offers a glimpse of environmental conditions in this region of the Antarctic during the LIA. The LIA or most recent Neoglacial (approximately 1500-1900 A.D.) is evident in northern hemisphere temperature (Groveman and Landsberg, 1979) and proxy (Lamb, 1977; Grove, 1988) records. Figure 5 presents the decadal averages of $\delta^{18} \mathrm{O}$ from the Siple core along with the 900 -year $\delta^{18} \mathrm{O}$ records from South Pole and the Quelccaya Ice Cap, Peru (Thompson and others, 1986).

The South Pole record (1050-1970 A.D.) is based upon ${ }^{18} \mathrm{O}$ measurements conducted at the University of Copenhagen from a core drilled in 1974 for Dr C.C. Langway, Jr. The $\delta^{18} \mathrm{O}$ data have been interpreted with the time scale based upon seasonal variations in particulate concentrations (Mosley-Thompson and Thompson, 1982) in the same core. The 1971-80 average is from a pit sampled in 1982 (Mosley-Thompson and others, 1985).

The $\delta^{18} \mathrm{O}$ records (Fig. 5) indicate that during much of the LIA conditions were warmer at Siple and cooler at South Pole than today. A few records from East Antarctica support the cooler LIA signal found at South Pole. The $\delta^{18} \mathrm{O}$ record from Law Dome (Morgan, 1985) shows a gradual cooling trend from the 1500 s which ends in the early $1800 \mathrm{~s}$ and is followed by a gradual warming to present (dating may be a problem). Morgan (1985; fig. 7)
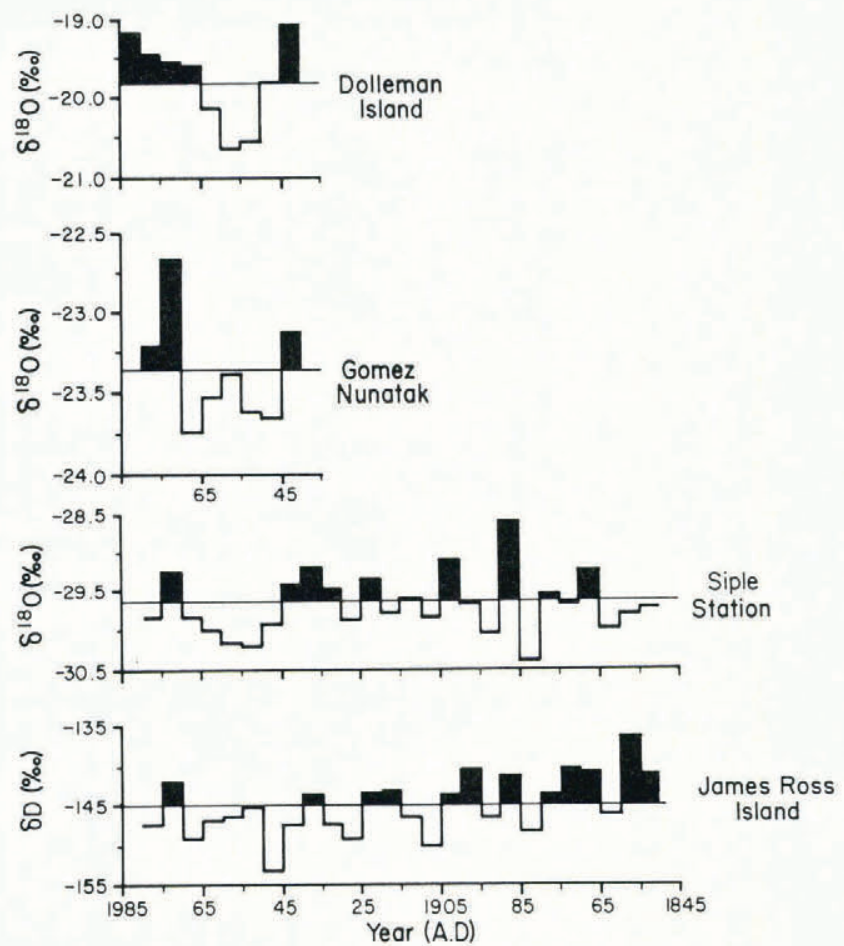

Fig. 4. Five-year averages of $\delta^{18} \mathrm{O}$ illustrated for the same four cores as in Figure 3, but Siple and James Ross records are extended to 1845 A.D.

also presented the Mizuho $\delta^{18} \mathrm{O}$ record (Japanese Antarctic Research Expedition) which indicates a broad cool period from the mid-1500s to the 1850s. A combined smoothed $8 D$ history from Dome C suggests cooler conditions from 1200 to 1800 A.D.; however, since significant noise necessitated high level smoothing the record requires further substantiation (Benoist and others, 1982).

In contrast, the Siple record is well dated, the high accumulation rate $\left(0.56 \mathrm{ma}^{-1} \mathrm{H}_{2} \mathrm{O}\right.$ eq. $)$ is nearly constant, and the $\delta^{18} \mathrm{O}$ signal is reproducible from core to core

\section{$\delta^{18} \mathrm{O}(\% \circ)$ Decadal Averages}

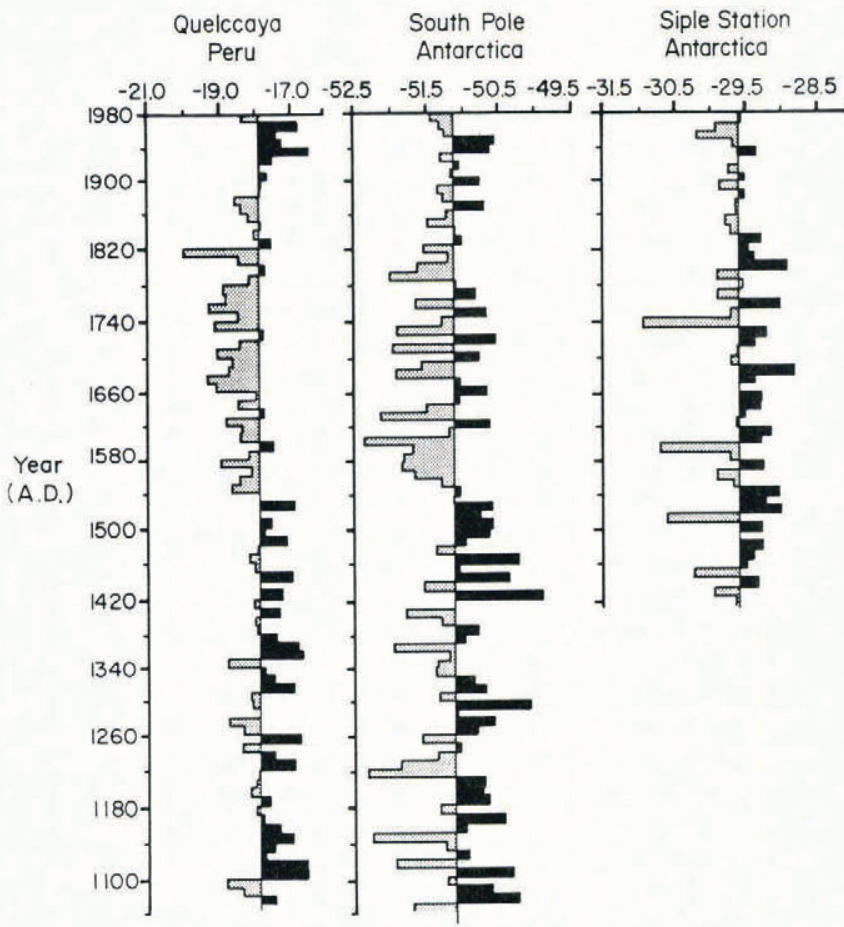

Fig. 5. Decadal averages of the $\delta^{18} \mathrm{O}$ record from Siple, South Pole and the Quelccaya Ice Cap, Peru are compared. Averages for each profile are based on the length of record illustrated. 
(Mosley-Thompson and others, 1989). Further, most of the broad temperature trends in the Peninsula region are reflected in the Siple $\delta^{18} \mathrm{O}$ record (note the 1945-55 exception). These data provide fairly strong evidence that the Siple region, and probably much of the Antarctic Peninsula area, were characterized by warmer than present conditions during the LIA. As discussed earlier, the $\delta^{18} \mathrm{O}$ record is interpreted here strictly in terms of temperature and other factors may account for, or contribute to, the ${ }^{18} \mathrm{O}$ enrichment.

More frequent and/or intense cyclonic activity could increase warm air advection to the continent and possibly suppress sea-ice extension. Parkinson (1990, this volume) examined LIA sea-ice limits using ship reports from early exploratory voyages to the Antarctic. The records which are admittedly scanty and temporally discontinuous showed no definitive evidence of sea-ice extension during the LIA Currently available $\mathrm{Cl}^{-}$and $\mathrm{SO}_{4}^{2-}$ concentrations (1965-85 and 1660-1865 A.D.) in the Siple core which could reflect major changes in sea-ice extent show small variation and no LIA signal. Increased storm frequency during winter might enrich (less negative) the annual average as storms tend to be associated with warmer than average temperatures. The 550-year record of net annual accumulation (converted to water equivalent, but not corrected for thinning with depth) shows no consistent increase during the LIA, although short (several decades) intervals of increase and decrease occur.

The difference between LIA conditions at South Pole and Siple is further supported by the insoluble particulate concentration records. The 5-year averages of insoluble dust concentrations and $\delta^{18} \mathrm{O}$ for Siple are illustrated in Figure 6. From 1630 to 1880 A.D. dust concentrations at Siple are lower than the 550-year average. One major dust event (1735 to 1755 A.D.) is associated with a negative (cooler) excursion in $\delta^{18} \mathrm{O}$. From 1880 to present dust concentrations have increased while the temperature has generally decreased. The positive relationship between increased dust deposition and cooler temperatures (inferred from $\delta^{18} \mathrm{O}$ ) is characteristic of glacial stage ice (Thompson and MosleyThompson, 1981; DeAngelis and others, 1987) as well as for the LIA (Mosley-Thompson and Thompson, 1982; Thompson and others, 1986). The dust concentration $-\delta^{18} \mathrm{O}$ relationship between Siple and South Pole supports this relationship; e.g.

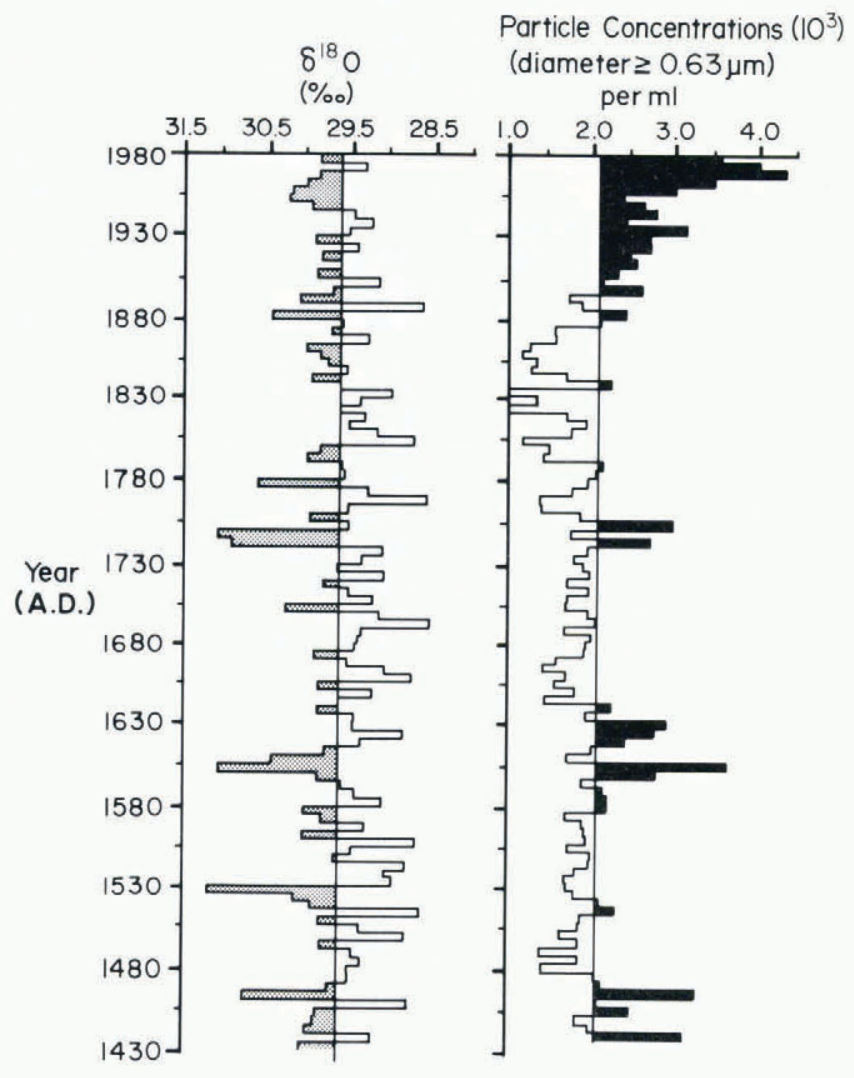

Fig. 6. The 5-year averages of $8^{18} \mathrm{O}$ and insoluble dust concentrations (diameter $\geqslant 0.63 \mu \mathrm{m}$ per ml sample) are illustrated for the Siple core. reduced dust deposition from 1630 to 1880 A.D. at Siple is associated with warmer conditions (less negative averages $8^{18} \mathrm{O}$ ) while increased dust deposition at South Pole is associated with cooler temperatures. Thus, the insoluble particulate concentrations further support an inverse relationship between environmental conditions at Siple Station and South Pole during much of the LIA.

\section{DISCUSSION}

The opposition in the Siple-South Pole $\delta^{18} \mathrm{O}$ and dust records during much of the LIA may reflect an increase in the persistence of atmospheric and oceanic conditions responsible for the currently observed temperature opposition. For example, intensification of the zonal westerlies leads to cooling at Amundsen-Scott and warming in the Peninsula region (Rogers, 1983). A prolonged period of intensified westerlies could explain the temperature pattern $\left(\delta^{18} \mathrm{O}\right)$ found in the Siple and Amunden-Scott cores.

The dissimilar dust concentrations probably reflect two different transport pathways from lower latitudes, the principal source of dust. Observations at South Pole (Hogan and others, 1984) indicate the terrestrial (Al and $\mathrm{Si}$ ) component of the aerosol mass is associated with an upper tropospheric or lower stratospheric source layer. Intensified westerlies at lower latitudes could entrain more material higher into the atmosphere and thus, increase the source of dust for the South Pole.

No similar aerosol studies have been conducted at Siple (accumulation rate $0.56 \mathrm{~m}^{-1}$ ) where frequent and severe storms dominate throughout the year. However, it is more likely that particulates deposited here have a lower tropospheric pathway associated with the passing cyclonic systems. Precipitation is an excellent mechanism for removal of entrained dust and thus lower tropospheric air reaching this region should be very clean (Hogan, 1975). The microparticle analyses support this (Mosley-Thompson and others, 1989). If increased cyclonic activity along the periphery of the continent accompanied the stronger westerlies (postulated), then the lower atmosphere should be cleansed further leading to the low concentrations characterizing 1630 to 1880 A.D. (Fig. 6). If this postulated increase in cyclonic activity resulted in more frequent storms at Siple, and hence increased net balance, the decrease in particulates could actually reflect a net accumulation increase. However, as noted earlier the 550-year net annual accumulation record does not show an increase during the LIA.

The similarity between the LIA $\delta^{18} \mathrm{O}$ records from South Pole and Quelccaya is intriguing. The excellent correspondence between the Quelccaya $\delta^{18} \mathrm{O}$ record and northern hemisphere temperatures (cooler) has been demonstrated (Thompson and others, 1986). The similarity between the South Pole and Quelccaya $\delta^{18} \mathrm{O}$ records suggest the possibility of large-scale upper atmospheric teleconnections between the South American Andes and the East Antarctic plateau. This warrents further investigation beyond the scope of this paper.

The different long-term trends in $\delta^{18} \mathrm{O}$ and particulate deposition at Siple and South Pole appear to be consistent with the current spatial distribution of temperature and atmospheric circulation regime. The physical processes controlling these spatial relationships must be better identified. Certainly such large regional differences indicate that a single ice-core record is insufficient to characterize the climatic history of an entire continent. Clearly, more high resolution paleoclimatic records from East and West Antarctica (including the Peninsula region) are necessary to characterize the spatial characteristics of the Little Ice Age signal in Antarctica.

\section{ACKNOWLEDGEMENTS}

We thank K. Mountain and J. Paskievitch for their participation in the field program. The ice cores were drilled by B. Koci, J. Litwak and K. Swanson of the Polar Ice Coring Office, Fairbanks, Alaska. L. Klein and $M$. Davis conducted the particulate analyses and their contribution to this work is gratefully acknowledged. T. 
Johnstone organized the meteorological data and the illustrations were drawn by $\mathrm{S}$. Smith and T. Temple. We especially thank Drs C.C. Langway, Jr. and W. Dansgaard for making their unpublished $\delta^{18} \mathrm{O}$ data from the 1974 South Pole ice core available. The constructive comments of two anonymous reviewers greatly improved the manuscript. This work was supported by National Science Foundation grant DPP-841032A04 to The Ohio State University and DPP-8400574 to the University of Washington. This is contribution 685 of the Byrd Polar Research Center.

\section{REFERENCES}

Aristarain, A.J., J. Jouzel, and M. Pourchet. 1986. Past Antarctic Peninsula climate (1850-1980) deduced from an ice core isotope record. Climatic Change, 8(1), 69-89.

Benoist, J.P., J. Jouzel, C. Lorius, L. Merlivat, and M. Pourchet. 1982. Isotope climatic record over the last $2.5 \mathrm{ka}$ from Dome C, Antarctica, ice cores. Ann. Glaciol., $3,17-22$.

Bromwich, D.H. and C.J. Weaver. 1983. Latitudinal displacement from main moisture source controls $\delta^{18} \mathrm{O}$ of snow in coastal Antarctica. Nature, 301(5896), 145-147.

Carleton, A.M. 1984. Associated changes in West Antarctic cyclonic activity and sea ice. In Environment of West Antarctica: potential $\mathrm{CO}_{2}$-induced changes. Washington, DC, National Academy Press, 96-106.

Dai, J., E. Mosley-Thompson, L.G. Thompson, and J.K. Arbogast. Submitted. Chloride, sulfate and nitrate in snow at Siple Station, Antarctica, 1965-1985. J. Glaciol.

De Angelis, M., N.I. Barkov, and V.N. Petrov. 1987. Aerosol concentrations over the last climatic cycle (160 kyr) from an Antarctic ice core. Nature, 325(6102), 318-321.

Department of Energy. 1987. A data bank of Antarctic surface temperature and pressure data. Dept. of Energy Technical Report 038.

Grove, J.M. 1988. The Little Ice Age. London, Methuen.

Groveman, B.S. and H.E. Landsberg. 1979. Simulated Northern Hemisphere temperature departures: 1579-1880. Geophys. Res. Lett., 6(10), 767-769.

Hansen, J. and S. Lebedeff. 1987. Global trends of measured surface air temperature. J. Geophys. Res., 92(D11), 13,345-13,372.

Hogan, A.W. 1975. Antarctic aerosols. J. Appl. Meteorol., 14(4), 550-559.

Hogan, A., K. Kebschull, R. Townsend, B. Murphey, J. Samson, and S. Barnard. 1984. Particle concentrations at the South Pole, on meteorological and climatological time scales; is the difference important? Geophys. Res. Lett., 11, (9), 850-853.

Jones, P.D., S.C.B. Raper, R.S. Bradley, H.F. Diaz, P.M. Kelly, and T.M.L. Wigley. 1986a. Northern Hemisphere surface air temperature variations: 1851-1984. J. Climate Appl. Meteorol., 25, 161-179.

Jones, P.D., S.C.B. Raper, and T.M.L. Wigley. 1986b. Southern Hemisphere surface air temperature variations: 1851-1984. J. Climate Appl. Meteorol., 25, 1213-1230.

Jouzel, J., L. Merlivat, J.R. Petit, and C. Lorius. 1983. Climatic information over the last century deduced from a detailed isotopic record in the South Pole snow. $J$. Geophys. Res., 88(C4), 2693-2703.

Lamb, H.H. 1977. Climate: present, past and future. Volume 2. Climatic history and the future. London, Methuen.
Limbert, D.W.S. 1984. West Antarctic temperatures, regional difference and the nominal length of summer and winter seasons. In Environment of West Antarctica: potential $\mathrm{CO}_{2}$ - induced changes. Washington, DC, National Academy Press, 116-139.

Morgan, V.I. 1985. An oxygen isotope-climate record from Law Dome, Antarctica. Climatic Change, 7(4), 415-426.

Mosley-Thompson, E. and L.G. Thompson. 1982. Nine centuries of microparticle deposition at the South Pole. Quat. Res., 17(1), 1-13.

Mosley-Thompson, E., P.D. Kruss, L.G. Thompson, M. Pourchet, and P. Grootes. 1985. Snow stratigraphic record at South Pole: potential for paleoclimatic reconstruction. Ann. Glaciol., 7, 26-33.

Mosley-Thompson, E., L.G. Thompson, J. Dai, P.M. Grootes, and N. Gundestrup. Submitted. Glaciological studies at Siple Station (Antarctica) and potential ice core paleoclimatic record. J. Glaciol.

Parkinson, C.L. 1990. Search for the Little Ice Age in Southern Ocean sea ice records. Ann. Glaciol., 14,

Peel, D.A., R. Mulvaney, and B.M. Davison. 1988. Stableisotope/air-temperature relationships in ice cores from Dolleman Island and the Palmer Land Plateau, Antarctic Peninsula. Ann. Glaciol., 10, 130-136.

Raper, S.C.B., T.M.L. Wigley, P.R. Mayes, P.D. Jones, and M.J. Salinger. 1984. Variations in surface air temperatures. Part 3. The Antarctic, 1957-82. Mon. Weather Rev., 112, 1341-1353.

Rogers, J.C. 1983. Spatial variability of Antarctic temperature anomalies and their association with the southern hemispheric circulation. Ann. Assoc. Am. Geogr., 73(4), 502-518.

Schwander, J. Unpublished. Lufteinschluss im Eis von Grönland der Antarktis. Messung der elektrischen Leitfähigkeit on Eisproben für klimatologische Anwendungen. (Ph.D. Dissertation, Universität Bern, 1984.)

Schwerdtfeger, W. 1976. Changes of temperature field and ice conditions in the area of the Antarctic Peninsula. Mon. Weather Rev., 104(11), 1441-1443.

Schwerdtfeger, W. and L.R. Amaturo. 1979. Wind and weather around the Antarctic Peninsula. Madison, WI, University of Wisconsin. Department of Meteorology.

Swanson, G.S. and K.E. Trenberth. 1981. Trends in the Southern Hemisphere tropospheric circulation. Mon. Weather Rev., 109(9), 1879-1889.

Thompson, L.G. and E. Mosley-Thompson. 1981. Microparticle concentration variations linked with climatic change - evidence from polar ice cores. Science, 212(4496), 812-815.

Thompson, L.G. and E. Mosley-Thompson. 1982. Spatial distribution of microparticles within Antarctic snow-fall. Ann. Glaciol., 3, 300-306.

Thompson, L.G., E. Mosley-Thompson, W. Dansgaard, and P.M. Grootes. 1986. The Little Ice Age as recorded in the stratigraphy of the tropical Quelccaya Ice Cap. Science, 234(4774), 361-364.

Trenberth, K.E. 1984. The atmospheric circulation affecting the West Antarctic region in summer. In Environment of West Antarctica: potential $\mathrm{CO}_{2}$-induced changes. Washington, DC, National Academy Press, 73-87.

Van Loon, H. and J. Williams. 1977. The connection between trends of mean temperature and circulation at the surface. Part IV. Comparison of the surface changes in the Northern Hemisphere with the upper air and with the Antarctic in winter. Mon. Weather Rev., 105, 636-647. 